\title{
Kıkırdağın iyi huylu tümörleri: Enkondrom ve osteokondromlar
}

\section{Benign cartilage tumors: enchondroma and osteochondroma}

\author{
H. Yusuf Yıldız \\ Ankara Üniversitesi Tıp Fakültesi, Ortopedi ve Travmatoloji Anabilim Dalı, Ankara
}

\begin{abstract}
Enkondromlar kemikte görülen, gerçek sıklığı bilinemeyen, iyi huylu kıkırdak tümörleridir. Cinsiyet farkı yoktur. En sık görüldükleri yerler eldeki tübüler kemiklerdir. Uzun kemiklerde ise femur, humerus ve tibiayı sık tutar. El ve ayaktaki enkondromlar travmaya sık maruziyet nedeniyle ağrı veya patolojik kırıklarla gelebilirken, uzun kemiklerdekiler genellikle ekleme ait ağrılar nedeni ile yapılan incelemelerde rastlantısal olarak saptanırlar. Kısa tübüler kemikler ile uzun kemiklerdeki radyolojik görünümleri farklılıklar gösterir. Kısa tübüler kemiklerde ekspansiyon yapmış ve korteksi inceltmiş, zor seçilen kalsifikasyonlar içeren kitleler şeklinde iken, uzun kemiklerde metadiyafizer yerleşimli, kortekste pek değişiklik yapmayan, pek çoğunda kalsifikasyonlar olan, sınırlandırılma görülmeyen lezyonlar halindedir. Enkondromatozis ve Mafucci sendromu alt gruplarını oluşturur. Asemptomatik olan enkondromları genellikle takip etmek yeterlidir. Cerrahi gerekecek ise küretaj ve greftlemek klasik tedaviyi oluşturur. Malign dönüşüm riski enkondromlarda \%1 civarı, çoklu lezyonlarda ise \%20-50 civarındadır. Enkondromlar ile düşük dereceli kondrosarkomları ayırt etmek klinisyen, radyolog ve patologlar için bazen çok zor olabilir; multidisipliner ortak çalışma bu zorlukları önlemede yarar sağlar.
\end{abstract}

Osteokondromlar kemiğin en sık görülen iyi huylu tümörüdür. Genellikle ilk iki dekatta fark edilirler. Erkeklerde biraz daha sıktır. EXT genlerinde mutasyon sonrası ortaya çıkarlar. Diz çevresinde, humerus proksimal, tibia distal ve femur proksimalde sık görülürler. Genelde ağrısız immobil şişlik şeklinde iken, etrafındaki yumuşak dokulara bası, bursit, kırık, aşırı büyüme ve ikincil kondrosarkom olması durumunda semptomatik olabilirler. Fizis kıkırdağından geliştikleri için boy uzaması durduğunda büyümez hale gelirler. Multipl osteokondromatozis otozomal dominant geçiş gösterir. Hastalarda deformiteler, kısa boy ve eklemler etrafında çok sayıda kemik çıkıntılar görülür. Malignite ihtimali soliter lezyonlarda \%1'den az iken, çoklu lezyonlarda \%5 civarındadır.

Anahtar sözcükler: kıkırdak hastalıkları; kondrom; osteokondrom
Enchondromas are benign bone tumors derived from cartilage cell. Real prevalance is unknown. There is no sex predilection. They are mostly found in the short tubular bones of the hand. Long bones, particularly femur, humerus and tibia are also involved. Enchondromas in the hand and foot present with pain or pathologic fractures due to frequent trauma, whereas long bone lesions are incidentally found during radilogical examinations for adjacent joint problems. Radiological findings differ for short tubuler and long bones. It manifests as an expansile lesion with cortical thinning and faint calcifications in short tubular bones, while in long bones a metadiaphyseal lesion is seen with irregular calcifications in most, but without sclerotic margins, that has minimal or no cortical changes. Enchondromatosis and Mafucci's syndrom are other forms of this disease. Followup is sufficient for asymptomatic enchondromas. Curettage and grafting is the classical treatment if surgery is required. Malignant change to low grade chondrosarcoma is seen in $1 \%$ of enchondromas and $20-50 \%$ in multiple lesions. It is sometimes very difficult to make a diagnosis between enchondroma and low grade chondrosarcoma for clinicians, radiologists and pathologists; multidisciplinary approach helps to overcome this problem.

Osteochondroma is the most common benign bone tumor, with a predilection for males. A mutation in the EXT genes is the reason. Symptoms usually arise in the first two decades. The common locations for osteochondromas are around the knee, proximal humerus, distal tibia and proximal femur. Flat bones may also be involved. Patients present with indolent, immobile bony prominences, but pressure on the neighboring soft tissues, bursitis, fracture, overgrowth of the lesion and malignant change also cause symptoms. Since these lesions arise from physeal cartilage, these lesions stop with the cessation of growth. Multiple osteochondromatosis is an autosomal dominantly inherited form with multiple exostoses, short stature and deformities. Risk of malignant change is less than $1 \%$ and estimated to be around $5 \%$ for solitary and multiple lesions, respectively.

Key words: cartilage diseases; chondroma; osteochondroma

- İletişim adresi: Prof. Dr. H. YusufYıldız, İbn-i Sina Hastanesi, Akademik Yerleşke K Blok 1. Kat, Samanpazarı, 06100 Ankara Tel: 0312 - 5082321 e-posta: yhyildiz@yahoo.com

- Geliș tarihi: 27 Eylül 2013 Kabul tarihi: 27 Ey/ül 2013 


\section{ENKONDROM (KONDROM)}

Matür hiyalin kıkırdaktan oluşan benign kıkırdak tümörüdür. En sık görülen şekli kemiğin içinde yerleşimli olan enkondromdur. Tümörlerin çoğu soliter olmakla birlikte, nadiren birden çok kemiği veya bir kemikte birden çok lokalizasyonu tutabilir. ${ }^{[1]}$ Çok daha düşük sıklıkla lezyon periost altında yerleşimli (periostal kondrom) veya yumuşak dokuda yerleşimli (yumuşak doku kondromu) olabilir. Enkondromlar soliter (en sık) veya multipl (Ollier hastalığı) olabilir. Ollier hastalığının beraberinde yumuşak doku hemanjiyomlarının olması durumunda Mafucci sendromu adını alır ve oldukça nadir görülür.

Kondromlar oldukça sık görülen tümörlerden olup, osteokondromlardan sonra gelir. Çeşitli serilerde, benign tümörlerin \%3-24'ünü oluşturduğu bildirilmiştir. $^{[2,3]}$ Enkondromlar genelde asemptomatik olduğundan, gerçek yaygınlıkları kesin olarak bilinemez, bundan dolayı belirtilen rakamlardan daha sık olduklarını düşünmek doğru olacaktır. Enkondromlar her iki cinste ve her yaş grubunda oldukça eşit dağılım gösterir. ${ }^{[4]}$ Olguların \%40-65’i elin küçük tübüler kemiklerinde yerleşiktir; sıklık sırası ile proksimal falankslar, metakarplar, orta falankslar ve nadiren distal falankslar tutulur, distal falanks tutulumu oldukça nadirdir. ${ }^{[5]}$ Tipik olarak metakarpların orta ve distal, falanksların ise daha çok proksimal kesimlerinde yerleşimlidir (Şekil 1). Ayağın tübüler kemikleri ele göre yedi kat daha az tutulur. Enkondromlar karpal ve tarsal kemiklerde hemen hiçbir zaman görülmez. Femur, humerus ve tibia uzun kemik enkondromlarının çok büyük kısmının görüldüğü yerler olup, radius ulna ve fibulada tutulum nadirdir. Yassı kemiklerde ise çok nadirdir. ${ }^{[6]}$

Mirra, fizisten çoğalarak kolonlar oluşturan kıkırdak hücrelerinin matriks kalsifikasyonu sonrasında ölmesi gerekirken, hayatta kalmaları ile enkondromların oluştuğunu söyler. ${ }^{[7]}$

Enkondromlar genelde asemptomatiktir. Pek çoğu, başka sebeplerle yapılan radyolojik incelemelerde rastlantısal olarak saptanır. Ağrı şikayeti ile gelen bir uzun kemik enkondrom hastasında, bu ağrının ekleme veya etrafındaki başka yapılara ait olup olmadığının belirlenmesi gerekir; aksi takdirde atipik bir enkondrom veya kondrosarkom ile karşı karşıya olunduğu düşünülebilir. Elin küçük kemiklerindeki kondromlarda olan ağrı ise, lezyonun kemiklerde yaptı̆̆ı ekspansiyon, kortikal incelme ve bunlara ikincil gelişen mikrokırıklara bağlı olarak sıkça görülür (Şekil 2). Büyük kemiklerde kondromlara bağlı patolojik kırık nadirdir. Kondromlar sintigrafide sıcak görüldüğünden, metastaz araştırılan hastalarda kondrom da varsa, yanlışlıkla metastatik odak olarak rapor edilebileceğini akılda bulundurmak

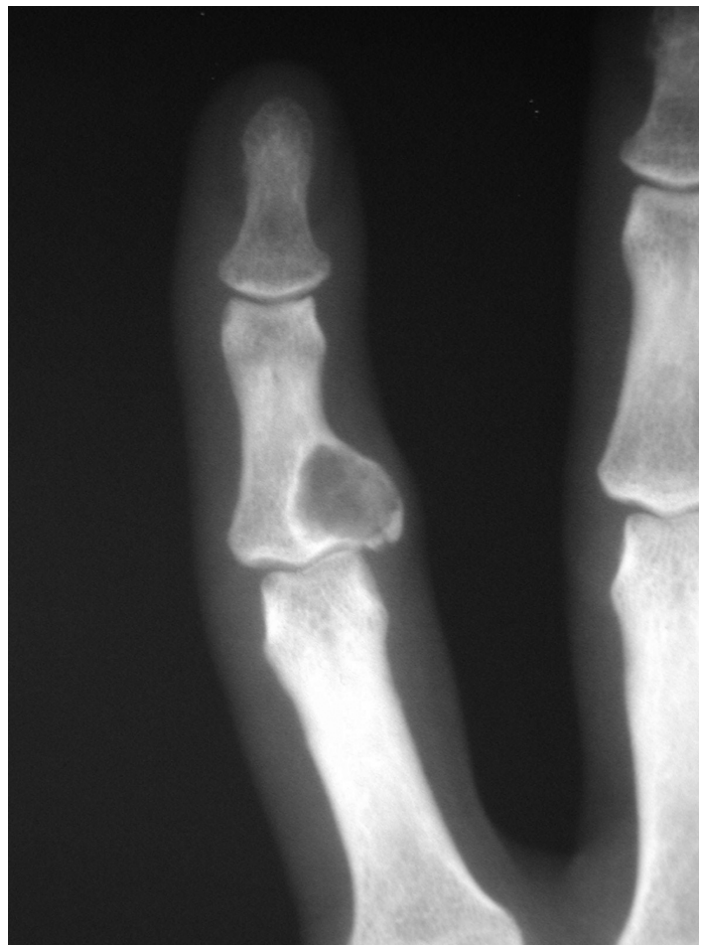

Şekil 1. İkinci parmak orta falanksta basise yerleşik, kemikte ekspansiyon yapmış lezyon.

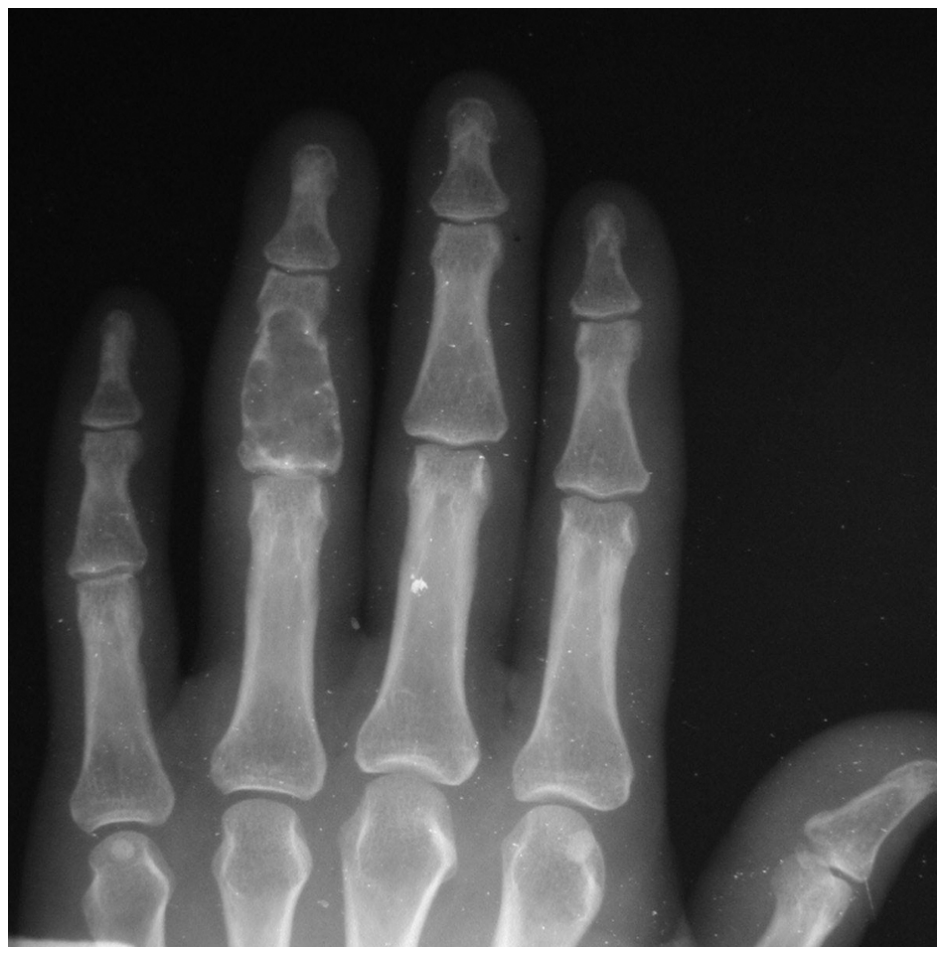

Şekil 2. Dördüncü parmak orta falanksta enkondrom. El travmaya çok sık maruz kaldığından patolojik kırık sıktır. 
gerekir. Küçük tübüler kemiklerde ekspansiyon yapmış olan kondromlarda, şişliğin palpe edilmesinden ve hassasiyetten başka fizik muayene bulgusu yoktur.

Gross olarak, içinde kalsifikasyonlar bulundurabilen, mavi-beyaz renkli lobüle fragmanlar şeklindedir.

Kondromların radyolojik özellikleri, bulundukları kemiğe göre farklılıklar gösterebilir. Küçük tübüler kemiklerde litik, etrafında sklerotik bir hat ile çevrelenmiştir, daha çok kemiklerin orta kısımları tutulur ama ucuna kadar uzanabilir; kitle kemikte ekspansiyona, kortekste incelmeye, ve bazan kırığa neden olabilir. Santral veya eksentrik yerleşimli olabilir. Mineralizasyon (kalsifikasyon veya ossifikasyon) radyolojik olarak her zaman net görülmeyebilir (Şekil 3). Uzun tübüler kemiklerde ise metafizer veya metadiafizer yerleşimli, normal kemikten net sınırlarla ayrılmayan lezyonlardır (Şekil 4). Kortekste genelde herhangi bir değişiklik olmamakla beraber, minik endosteal yeniklikler, hafif ekspansiyon ve minimal kortikal kalınlaşma da görülebilir. İçinde hemen her zaman kalsifikasyon vardır, fakat değişik oranlarda bulunduğundan, bazan direkt grafide saptanamayabilir. ${ }^{[6]}$ Bilgisayarlı tomografi (BT) matriks kalsifikasyonunu, korteksteki değişiklikleri diğer yöntemlerden daha iyi göstermekle beraber, medullada boyut ölçümü, yumuşak doku komponentinin varlığı ve lezyonun lobüler yapısı manyetik rezonans (MR) görüntülemede daha iyi anlaşılır (Şekil $5 \mathrm{a}, \mathrm{b}$ ). ${ }^{[8]}$

Enkondromların boyu, uzun kemiklerde nadiren 6 cm'yi aşar. ${ }^{[6]}$
Rastlantısal olarak saptanan küçük boyutlu kondromların yılda bir kez radyolojik olarak kontrol edilmesi yeterlidir. Semptomatik veya büyük boyutlu lezyonlarda ise klasik tedavi küretaj ve greftlemedir. Nüks oranları \%10'un altındadır.

Küçük kemik kondromlarının ayırıcı tanısında anevrizmal kemik kisti, dev hücreli reparatif granülom, uzun kemiklerde ise kemik infarktı (bone infarct) ve kondrosarkom vardır. Özellikle düşük dereceli kondrosarkom ile enkondrom tanıları arasında karar vermek, klinik, radyolojik ve histolojik olarak bazen çok zor olabilir. Kıkırdak tümörlerinin malign olma olasılı̆̆ı, periferden aksiyel iskelete doğru yaklaştıkça artar. Aksiyel iskelette ve sternumda $4 \mathrm{~cm}$ 'den küçük olan lezyonların benign olduğunu söyleyebilmek için, ekspansiyon, derin kortikal yeniklik, periostit ve yumuşak doku kitlesinin olmaması gerekir. ${ }^{[6]}$ En büyük zorluk, uzun kemik kıkırdak tümörlerinde yaşanır. Kondrosarkomu olan hastaların neredeyse tamamında ağrı şikayeti vardır. Ekleme yakın enkondromu olan hastalarda ise ağrı dejeneratif eklem hastalığına, rotator manşet sorununa veya başka eklem etrafı sorunlara ait olabilir. Otuz yaş üzerindeki hastalarda, uzun kemiklerin epifizlerinde saptanan kıkırdak tümörlerinin malign olma ihtimali yüksektir. Kortekste büyük yenikliklerin olması, kortikal ekspansiyon, incelme veya kalınlaşma, kortikal destrüksiyon, yumuşak doku kitlesinin olması, lezyonun matriksinde flulaşma ve boyutlarının 5-6 cm'den büyük olması, uzun kemik kondromları için malignite şüphesi uyandırmalıdır. ${ }^{[6]}$

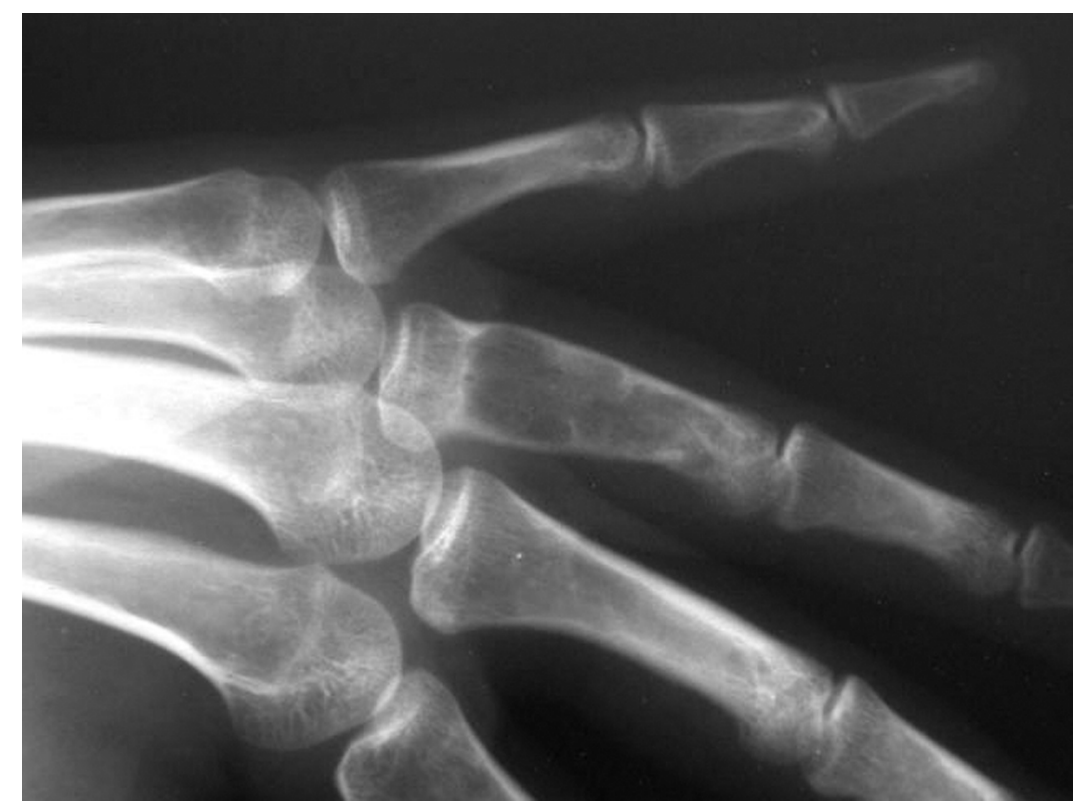

Şekil 3. Tipik el enkondromu; kemiği ekspanse edip korteksi incelten, iyi sınırlı, içinde net kalsifikasyon görülmeyen lezyon.

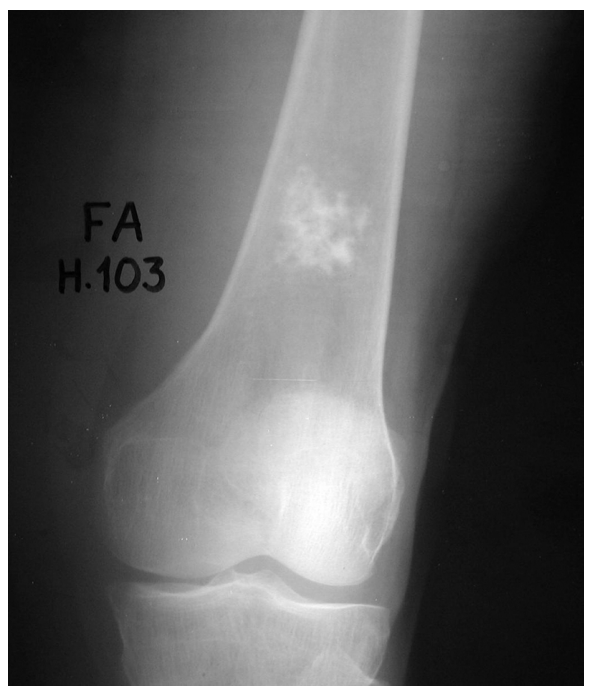

Şekil 4. Femur distal diyafizometafizer yerleşimli bu lezyon kalsifikasyonları sayesinde kolayca tanınabilir. Çok uzun zamandır var olan bu enkondromun kemik tarafindan hiç sınırlandırılmadığına dikkat ediniz. 

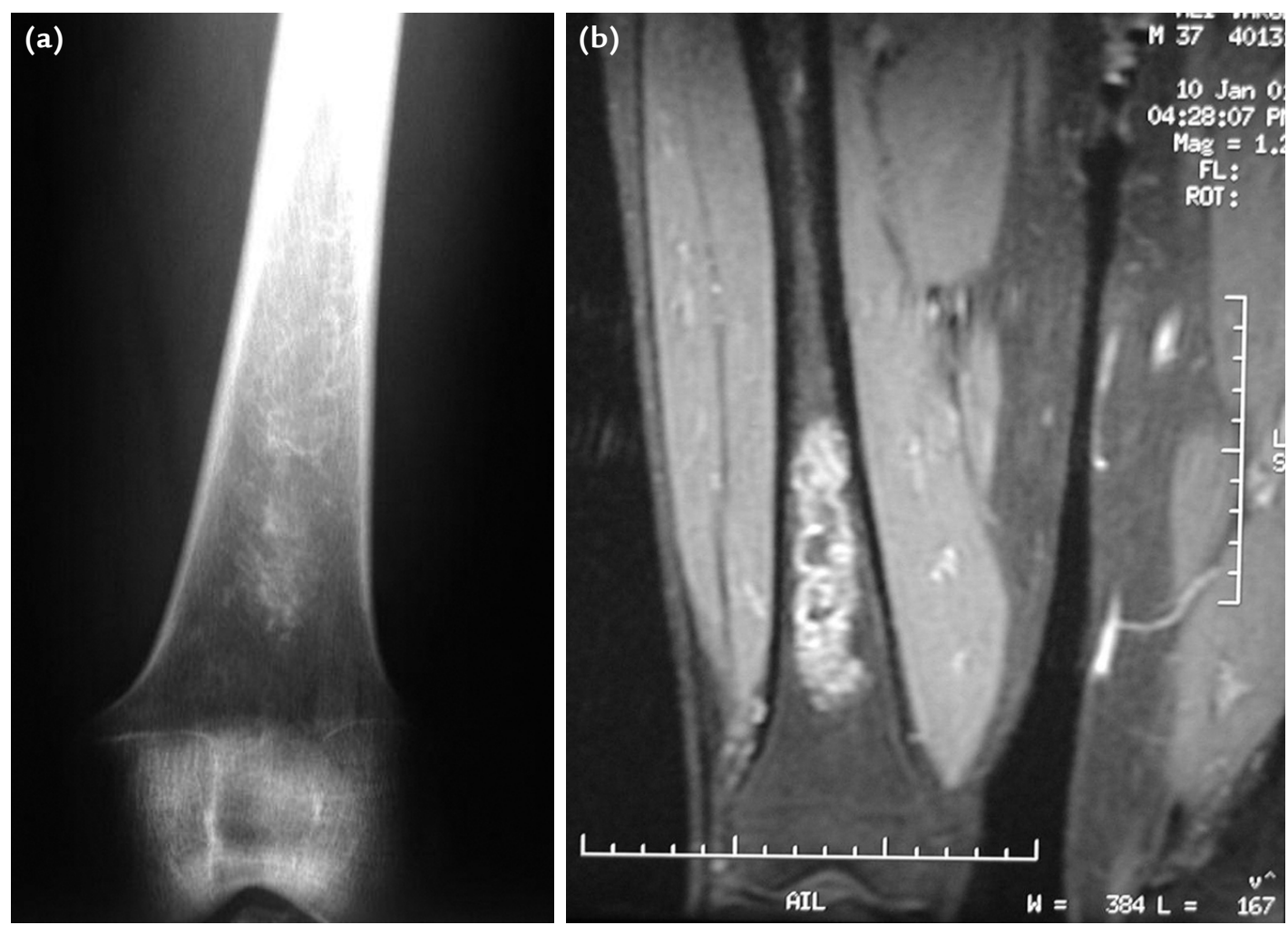

Şekil 5. a, b. Metadiyafizer yerleşimli bu lezyonun (a) MR incelemede boyutunun $9 \mathrm{~cm}$ üzerinde olduğu ölçüldü (b). Bu kadar büyük olması malignite için endişe ettirse de, başka malignite kriteri bulunmamakta. Açık biyopsi ve sonrasında yapılan küretajın patoloji sonuçları enkondrom olarak rapor edildi.

\section{Ollier hastalı̆̆}

Enkondromatozis olarak da adlandırılır; birden çok kemikte enkondromun olmasıdır. Ailevi geçiş göstermez. Birkaç kemik tutulabileceği gibi, yaygın tutulum da görülebilir. Bir taraftaki lezyonların daha belirgin olmaya eğilimi vardır. Uzun kemiklerde olduğu gibi, yassı kemiklerde de görülür. Boy kısalığı, ekstremiteler arası uzunluk farklılığı, kemiklerde ve eklemlerde açısal deformiteler, asimetrik büyümeler sıklıkla görülür. Tutulan kemiklerdeki diyafizler kısa ve genişlemiştir, metafizer kısımlara yaklaştıkça eğilmeler görülebilir. ${ }^{[9]}$ Fizisten metafize doğru kolonlar tarzında uzanan kıkırdak kümeleri radyografilerde görülür (Şekil 6). Bu kıkırdak kümelerinin üzerinde genellikle kortikal kemik pek bulunmaz. Kıkırdağın büyük kısmında kalsifikasyon vardır.

Hastalarda malignite gelişme ihtimali \%20-50 arasında bildirilmiştir. ${ }^{[10]}$

\section{Mafucci sendromu}

Ollier hastalığı ile beraber yumuşak doku hemanjiyomlarının olması durumudur. Ollier hastalığındaki kıkırdak lezyonları ile birlikte, flebolitler nedeniyle, hemanjiyomlar da röntgen filmlerinde saptanır (Şekil 7 a, b). Çok nadir görülen bu hastalıkta, hastaların büyük kısmında malignite gelişir; bunlar kıkırdak orijinli olabildiği gibi, genelde ilgisiz organların kanserleri şeklinde de olabilir.

Klinik sorun oluşturmadığı sürece Ollier hastalığı ve Mafucci sendromunda tedaviye gerek yoktur. Patolojik kırık olduğu takdirde, deformite/boy eşitsizliğinde ve malign dönüşüm durumunda cerrahi tedavi gerekir.

Ollier hastalığı ve Mafucci sendromunda, kıkırdak lezyonlarının displastik fizis plağı döküntülerinden geliştiği kabul edilmektedir. Her iki durumda da hastalara, hastalıkları ile ilgili bilgi verilmeli ve düzenli aralar ile kontrolleri yapılmalıdır.

\section{OSTEOKONDROM (EKSOSTOZ)}

Osteokondrom veya daha sık kullanılan adı ile eksostozlar kemiğin en sık görülen benign tümörüdür ve tüm kemik neoplazmlarının \%10-15'ini, benign kemik tümörlerinin \%20-50'sini oluşturur. ${ }^{[11,12]}$ Aynı zaman$\mathrm{da}$, çocukluk çağının da en sık görülen tümörüdür. 


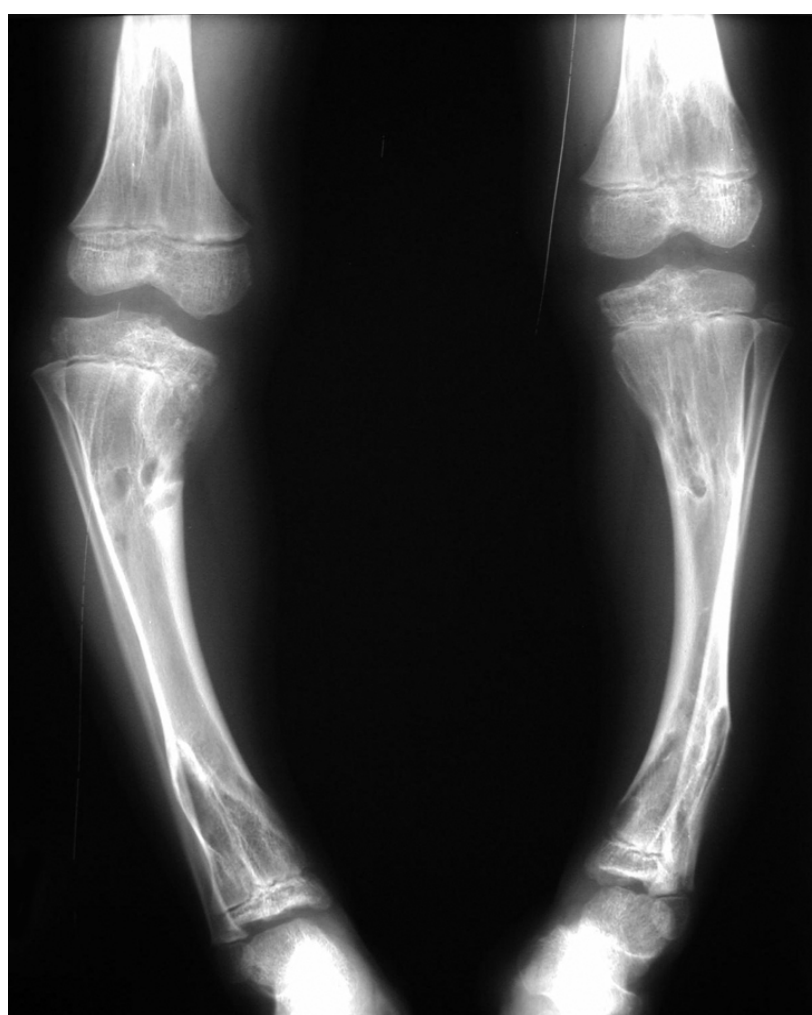

Şekil 6. Kolonlar tarzında kıkırdak kümeleri ve bilateral tibia vara deformitesi ile klasik bir Ollier hastalığı olgusu. Bu hastaya korrektif osteotomiler yapılmasına rağmen deformitesi üç yıl içinde tekrar etti.

Soliter veya birden çok sayıda olabilir; çok sayıda olduğunda multipl herediter eksostoz (MHE) veya diyafizer aklazi adını alır. Soliter lezyonu olan hastalar 4-5 kat daha sıktır. ${ }^{[13]}$ Erkeklerde kadınlara oranla yaklaşık iki kat daha sık görülür. Olguların \%75'i ilk iki dekatta ortaya çıkar. ${ }^{[12]}$

Osteokondromlar enkondral ossifikasyonun olduğu tüm kemiklerde olabilir. En sık görüldükleri yerler uzun kemiklerin metafiz veya daha nadiren metadiyafizleridir. Femur distali, humerus proksimali, tibia proksimali, femur proksimali, ve ilium en sık görüldükleri yerlerdir. ${ }^{[12,13]}$

Soliter osteokondromların oluşumunda exostosin 1'i (EXT1) kodlayan gende oluşan mutasyonların rol oynadığı gösterilmiştir. ${ }^{[14]}$ EXT1 ve EXT2 proteinleri heparan sülfat proteoglikanlarının (HSPG) sentezlenmesinde rol alır. HSPG'ler fiziste ekstrasellüler ortamda Indian hedgehog $(\mathrm{IHH})$ ligandlarına bağlanarak $\mathrm{HH}$ ligandlarının dağılımını kontrol eder. EXT genlerindeki mutasyonlar anormal HSPG'lerin hücre dışına çıkamamasına ve $\mathrm{IHH}$ 'lerin ekstrasellüler ortamda iyice yayılmasına sebep olur ve bu da büyüme plağı kondrositlerinin
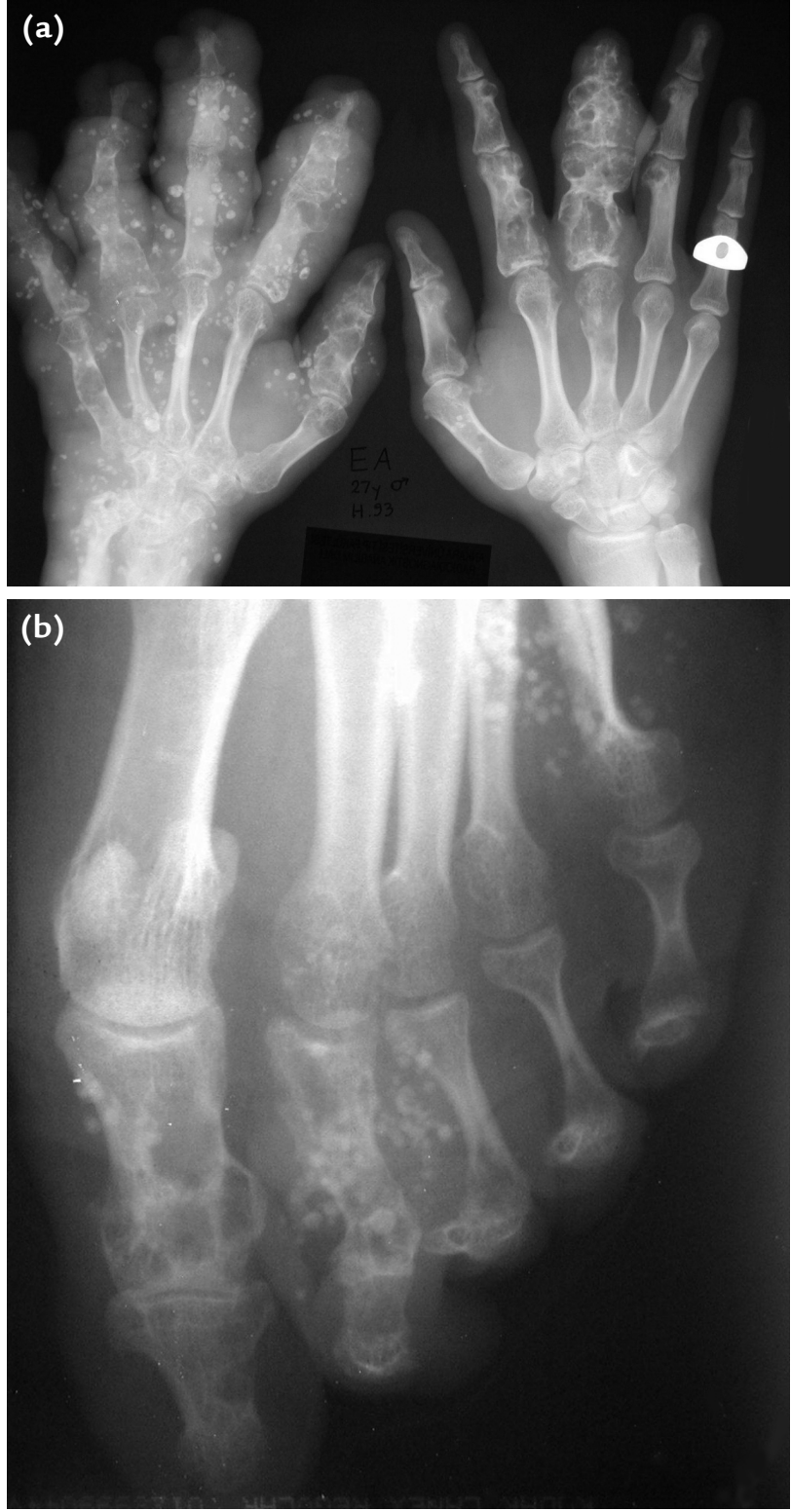

Şekil 7. a, b. Mafucci sendromu. Enkondromların bir tarafta daha baskın olduğu görülüyor. Flebolitler nedeni ile hemanjiyomlar kolayca tanımlanabiliyor (a). Hastanın ayağında da benzer görünüm var (b).

kutupsal organizasyonunu bozarak yanlış yönde büyümelerine sebep olur. ${ }^{[15,16]}$ Böylece eksostozlar, ağacın dal vermesi gibi, gelişirler; lezyonun korteksi normal kemik korteksi ile ve lezyonun medullası da kemiğin medullası ile devamlılık gösterir.

Hastalar uzun zamandır mevcut olan ve yavaş büyüyen sert şişlik şikayeti ile başvururlar. Fizik muayenede palpe edilen sert ve immobil kitleden başka bulgu yoktur. Osteokondromların en ciddi komplikasyonu 

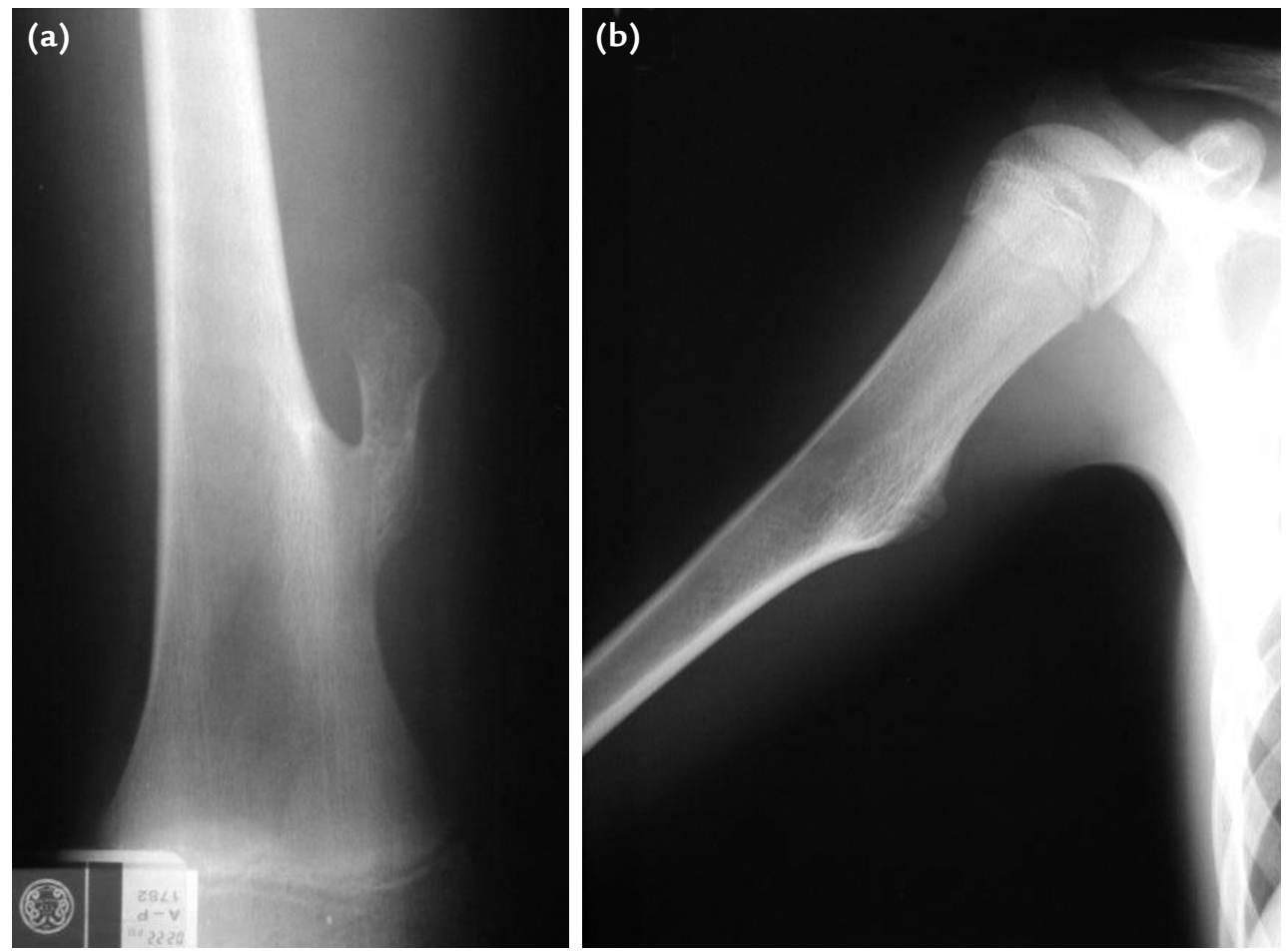

Şekil 8. a, b. Saplı (a) osteokondromlar sesil (b) olanlara göre daha sık görülürler.

\%1'den az görülen ikincil kondrosarkom gelişmesidir. Diğer komplikasyonları ise bu şişliğin etraf yumuşak dokulara (özellikle damar ve sinir yapılarına) bası yapması, lezyon üzerinde bursit gelişimi veya nadiren pedikülünden kırılması ve deformite sayılabilir. Damar basısı nedeniyle stenoz/oklüzyon, sıkışma sendromu veya psödoanevrizmalar görülebilir. ${ }^{[17,18]}$ Deformite, lezyonun kendisine, fizisin etkilenmesine ve lezyonun diğer kemiklere basısına bağlı görülebilir; çift kemikli yerlerde sinostoz dahi gelişebilir. ${ }^{[19]}$

Gross olarak, kemiğin üzerinde çıkıntı yapmış bir kemik kitle ve bu çıkıntının da üzerini kaplayan kıkırdak doku şeklinde görülür. Lezyonlar saplı (pedunculated daha sık) veya sesil (geniş tabanlı, daha az yükseklikte) olabilir (Şekil 8 a, b). Kıkırdak şapka, büyüme kıkırdağı ile aynı özellikte olan hiyalin kıkırdaktan oluşur.

Radyolojide osteokondromun kaynaklandığı kemik ile kortikal ve meduller devamlılığı görülür (Şekil 9). Kıkırdak şapkada kalsifikasyonlar görülebilir, ancak yoğun kalsifikasyon ve arada lusent sahalar var ise malign dejenerasyon akla getirilmelidir. Osteokondromlar genellikle en yakındaki eklemin ters yönünde uzanım gösterir. Kıkırdak şapkanın kalınlığının erişkinlerde 2 cm'nin üzerinde olması kondrosarkom lehinedir. ${ }^{[20]}$ Çocuklarda ise $3 \mathrm{~cm}$ üzeri kalınlık riskli kabul edilir. Bu kalınlık ultrasonografi, BT veya en iyi MR ile ölçülebilir.
Bursitle beraber olan ağrılı osteokondromların MR ile incelenmesinde, kontrast madde kullanılmaması durumunda, yanlışlıkla kıkırdak şapka kalınlığının fazla ölçüleceği akılda bulundurulmalıdır.

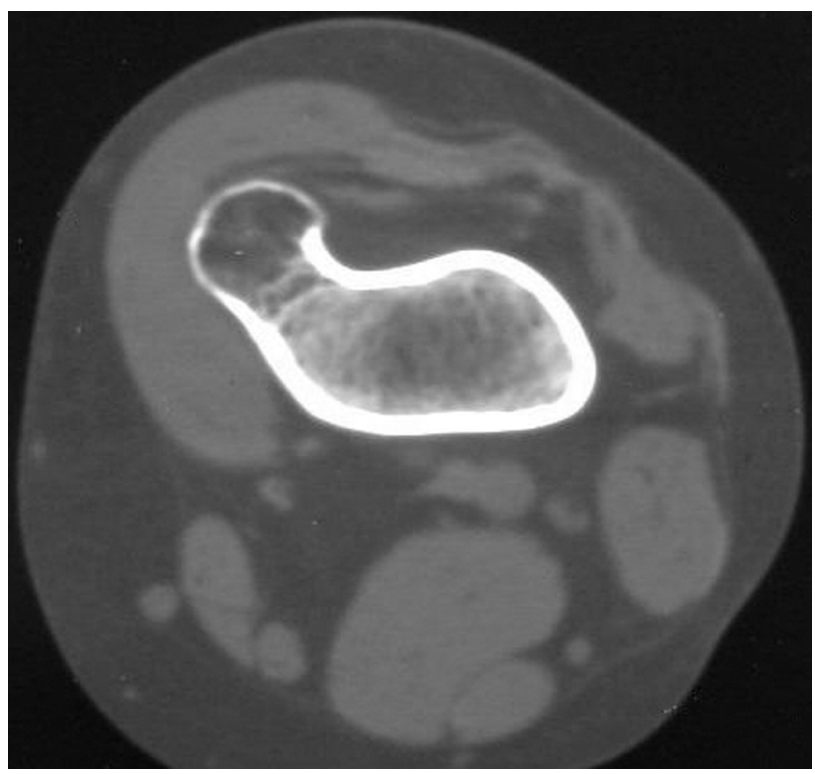

Şekil 9. Osteokondrom tanısının konabilmesi için kortikal ve meduller devamlılı̆̆ın görülmesi gerekir; bu da en iyi BT ile gösterilir. 


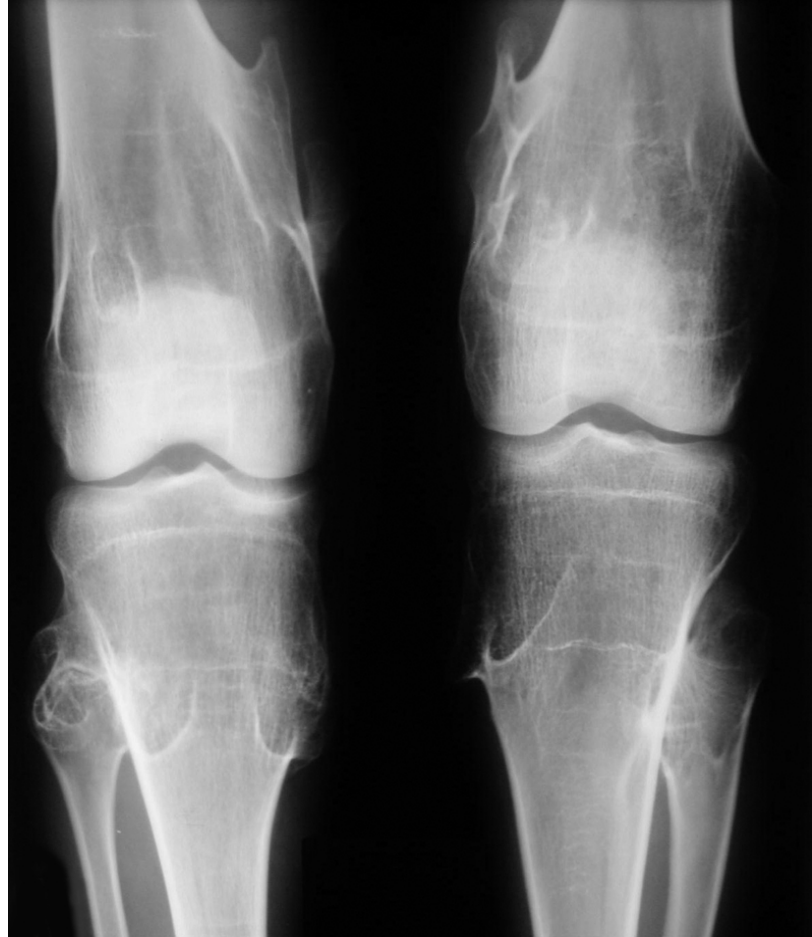

Şekil 10. MHE'de her iki diz çevresinde çok sayıda lezyonun olduğu ve metafizlerin genişlediği görülüyor.

Hastaya rahatsızlık oluşturmayan osteokondrom varlığında, hasta düzenli aralıklarla radyolojik kontrole çağrılır. Eğer lezyon fonksiyonları engeller, üzerinde oluşan bursa inflame olur, pediküllü lezyonların sapı kırılır ise cerrahi olarak çıkartılır. İskelet büyümesi tamamlandıktan sonra osteokondromun büyümeye devam etmesi, travma olmaksızın ağrımaya başlaması ve önceden belirgin olan radyolojik sınırlarının bulanıklaşıp, belirsiz hal alması durumunda, aksi ispatlanıncaya dek ikincil malign dejenerasyon düşünülmelidir.

\section{Multipl herediter eksostoz (MHE)}

Otozomal dominant geçiş gösterir. Spontan mutasyon ile de başlayabilir. X kromozomuna bağlı değişken penetrans gösterdiği için kadınlarda daha hafif bir klinik vardır. EXT1 (8q23-q24) ve EXT2 (11p11-p12) genlerindeki mutasyonlar nedeniyle MHE ortaya çıkar. ${ }^{[21]}$ Ayrıca 19. kromozomun kısa koluna yerleşik EXT3 geninin de rolü olduğu düşünülmektedir.[22]

Lezyonlar soliter osteokondromların sayıca çok ve biraz abartılmışı şeklindedir (Şekil 10). Osteokondromların olduğu her kemikte, taraf ayırt etmeden, görülür. Erkeklerde kadınlara oranla iki kat daha sıktır. Hastalar ağrısız kemik şişlikler ile genelde ilk, en geç ikinci dekatta başvururlar; klinik olarak tanı koymak çok kolaydır. Eklem yakınlarında çıkıntılar, kısa

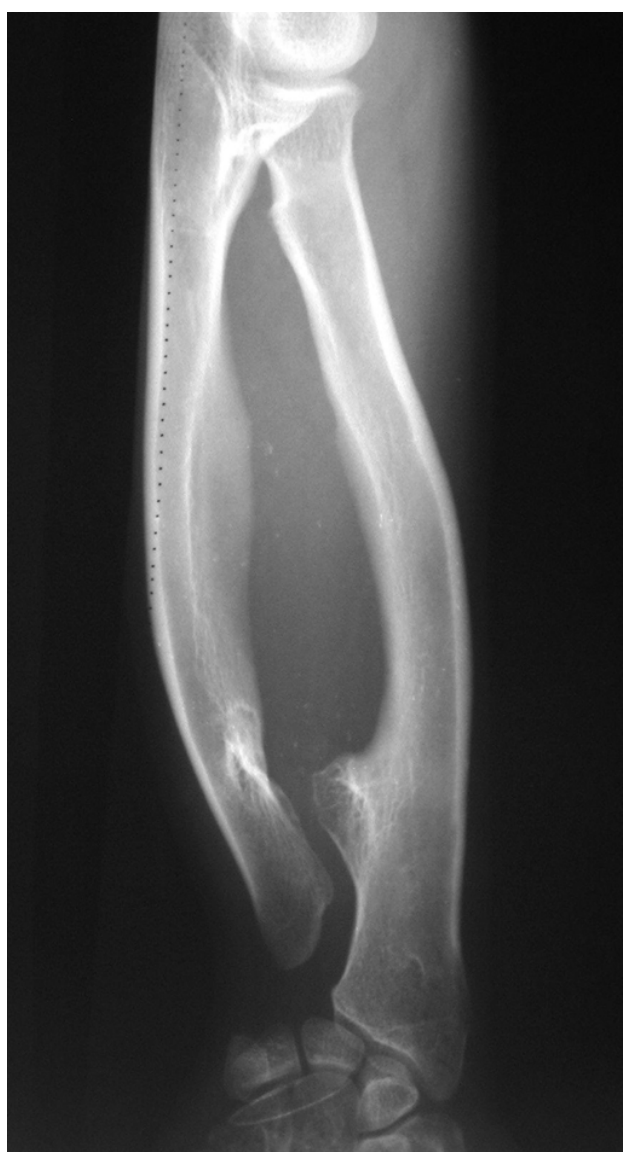

Şekil 11. MHE için patognomonik görünüm: distali yeterince gelişmemiş kısa ulna ve ulnaya doğru eğilmiş, distal eklem yüzünü açısı bozulmuş radius ve kısa bir önkol.

boy ve şiddetli olgularda, ekstremitelerde deformiteler (en sık olarak ulna distalinde kısalık, radiusta eğrilik), boy eşitsizlikleri görülür (Şekil 11). Deformitelere ve eklemlere yakın çıkıntılara bağlı olarak, hareket kısıtlılıkları da ortaya çıkabilir. Soliter osteokondromlarda normal olan uzun kemik tubulasyonu MHE'de bozulmuştur; bundan dolayı genişlemiş metafizler, kısa ve kalın femur boynu görülebilir.

Histopatolojik özellikleri soliter osteokondrom ile aynıdır.

MHE'de dikkat edilmesi gereken husus, ikincil malignite gelişmesi olasılığının \%5 civarında olmasıdır. ${ }^{[23]}$ En sık ikincil kondrosarkom görülür; fibrosarkom veya osteosarkom da gelişebilir (Şekil 12 a, b). Bulguları soliter osteokondrom üzerinde gelişen ikincil malignite bulguları ile aynıdır.

MHE'nin ayırıcı tanısında dysplasia epiphysealis hemimelica (Trevor hastalığı), metakondromatozis, LangerGiedion sendromu ve Potocki-Schaffer sendromu bulunur. ${ }^{[9,23]}$ 

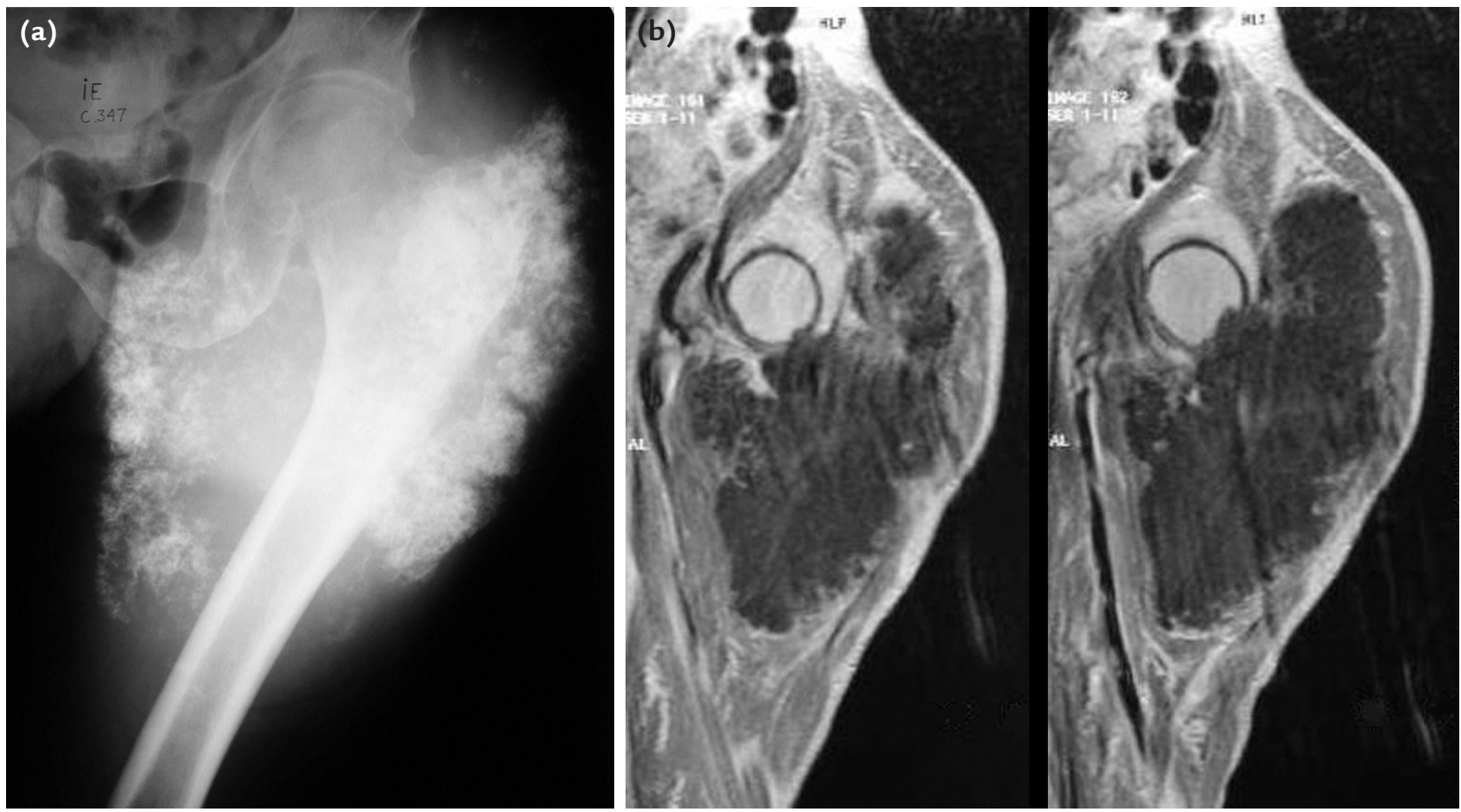

Şekil 12. a, b. MHE'si olan bir hastada ikincil kondrosarkom (a). Lezyonlar uzun yıllar boyunca yavaş büyüme gösterebilir; bu hastanın 15 yılı aşkın sürede gelişen ve 29 cm boya ulaşan kitlesi kalça dezartikülasyonu ile çıkartıldı (b).

\section{KAYNAKLAR}

1. Lucas DR, Bridge JA. Chondromas: enchondroma, periosteal chondroma, and enchondromatosis. In: Fletcher CDM, Unni KK, Mertens F, editors. World Health Organization Classification of Tumours. Pathology and Genetics of Tumours of Soft Tissue and Bone. Lyon: IARC Press; 2002. p.237-40.

2. Unni KK. Enchondroma and chondrosarcoma. In: Unni KK, editor. Dahlin's Bone Tumors: General Aspects and Data on 11,087 cases. 5th ed. Philadelphia: Lippincott-Raven; 1996.

3. Nielsen GP, Rosenberg AE. Enchondroma. In: Nielsen GP, Rosenberg AE, editors. Diagnostic Pathology Bone. Altona, Manitoba: Amirsys; 2013.

4. Romeo S, Hogendoorn PC, Dei Tos AP. Benign cartilaginous tumors of bone: from morphology to somatic and germ-line genetics. Adv Anat Pathol 2009;16(5):307-15. CrossRef

5. Resnick D, Kyriakos M, Greenway GD. Tumors and tumor-like lesions of bone: Imaging and pathology of specific lesions. In: Resnick D, editor. Diagnosis of Bone and Joint Disorders, 3rd ed. Philadelphia: WB Saunders; 1995. p.3629-47.

6. FlemmingDJ, MurpheyMD. Enchondroma and chondrosarcoma. Semin Musculoskeletal Oncol 2000;4(1):59-71.

7. Mirra JM, Eckardt JJ. Intramedullary Cartilage and Chondroid producing Tumors. In: Mirra JM, editor. Bone Tumors: Clinical, Radiologic and Pathologic correlations. Philadelphia: Lea and Febiger; 1989. p.439-690.

8. Murphey MD, Flemming DJ, Boyea SR, Bojescul JA, Sweet DE, Temple HT. Enchondroma versus chondrosarcoma in the appendicular skeleton: differentiating situations. Radiographics 1998;18(5):1213-37.
9. Pannier S, Legeai-Mallet L. Hereditary multiple exostoses and enchondromatosis. Best Pract Res Clin Rheumatol 2008;22(1):45-54. CrossRef

10. Bovée JV, Graadt van Roggen JF, Cleton-Jansen AM, Taminiau $\mathrm{AH}$, van der Woude HJ, Hogendoorn PC. Malignant progression in multiple enchondromatosis (Ollier's disease): an autopsy-based molecular genetic study. Hum Pathol 2000;31(10):1299-303.

11. Brien EW, Mirra JM, Luck JV Jr. Benign and malignant cartilage tumors of bone and joint: their anatomic and theoretical basis with an emphasis on radiology, pathology and clinical biology. II. Juxtacortical cartilage tumors. Skeletal Radiol 1999;28(1):1-20.

12. Murphey MD, Choi JJ, Kransdorf MJ, Flemming DJ, Gannon $\mathrm{FH}$. Imaging of osteochondroma: variants and complications with radiologic-pathologic correlation. Radiographics 2000;20(5):1407-34.

13. Saglik Y, Altay M, Unal VS, Basarir K, Yildiz Y. Manifestations and management of osteochondromas: a retrospective analysis of 382 patients. Acta Orthop Belg 2006;72(6):748-55.

14. Hameetman L, Szuhai K, Yavas A, Knijnenburg J, van Duin $M$, van Dekken $\mathrm{H}$, Taminiau AH, Cleton-Jansen AM, Bovée JV, Hogendoorn PC. The role of EXT1 in nonhereditary osteochondroma: identification of homozygous deletions. J Natl Cancer Inst 2007;99(5):396-406.

15. Bovée JV, Hogendoorn PC, Wunder JS, Alman BA. Cartilage tumors and bone development: molecular pathology and possible therapeutic targets. Nat Rev Cancer 2010;10(7):4818. CrossRef

16. Garcia RA, Inwards CY, Unni KK. Benign bone tumors-recent developments. Semin Diagn Pathol 2011;28(1):73-85. 
17. Guy NJ, Shetty AA, Gibb PA. Popliteal artery entrapment syndrome: an unusual presentation of a fibular osteochondroma. Knee 2004;11(6):497-9.

18. Argin M, Biçeroğlu S, Arkun R, Parildar M. Solitary osteochondroma causing popliteal pseudoaneurysm that presented as a mass lesion. Diagn Interv Radiol 2007;13(4):190-2.

19. Bozkurt M, Doğan M, Turanli S. Osteochondroma leading to proximal tibiofibular synostosis as a cause of persistant ankle pain and lateral knee pain: a case report. Knee Surg Sports Traumatol Arthrosc 2004;12(2):152-4.

20. Bernard SA, Murphey MD, Flemming DJ, Kransdorf MJ. Improved differentiation of benign osteochondromas from secondary chondrosarcomas with standadized measurement of cartilage cap at $\mathrm{CT}$ and MR imaging. Radiology 2010;255(3):857-65. CrossRef
21. Cook A, Rasking W, Blandon SH, Pauli RM, Gregg RG, Francomano CA, Puffenberger E, Conrad EU, Schmale G, Schellenberg G, et al. Genetic heterogeneity in families with hereditary multiple exostoses. Am J Hum Genet 1993;53(1):71-9.

22. Le Merrer M, Legeai-Mallet L, Jeannin PM, Horsthemke $B$, Schinzel A, Plauchu $H$, Toutain A, Archard F, Munnich A, Maroteaux P. A gene for multiple hereditary exostoses maps to chromosome 19p. Hum Mol Genet 1994;3(5):717-22.

23. Robbin MR, Murphey MD. Benign chondroid neoplasms of bone. Semin Musculoskelet Radiol 2000;4(1):45-58. 